\title{
Affective and Cognitive Information Behavior: Interaction Effects in Internet Use
}

\author{
Diane Nahl \\ Library and Information Science Program, Department of Information and Computer Sciences, University of Hawaii, \\ 1680 East-West Road, Honolulu, HI 96822. nahl@hawaii.edu
}

The presence and influence of affective variables in information behavior was studied. Affective load (AL), a compound variable consisting of uncertainty and technophobia measures, was found to be present in a variety of simple and complex information tasks integrated into upper-division, disciplinary coursework. Affective load was higher in those who reported low values of affective coping skills and who had either high or low cognitive assessment scores.

Affective coping skills (ACS) consist of self-efficacy (SE) and optimism (Op) measures. High self-efficacy and optimism have been found to significantly and beneficially influence success in a variety of information tasks, by counteracting the effects of negative emotions such as irritation and frustration. In this study, high coping skills provided a significant affective advantage as indicated by higher optimism, stronger self-efficacy, lower uncertainty, higher support and acceptance of the system and lower affective load. The group with high cognitive skills reported significantly higher optimism, higher affective coping skills and higher felt exercise of control, demonstrating an interaction between cognitive and affective skills. There was a distinct advantage for those who had both high affective coping skills and high cognitive skills. They experienced relatively low affective load and high acceptance of the system.

Introduction 
Affective load theory (ALT) was described in a previous study with operational definitions for measuring several compound dimensions of affect in information behavior (Nahl, 2004; 2005). Affective Load was defined as uncertainty intensified by felt time pressure (U*TP) $(2004,195)$. It was shown that acquiring Internet literacy and adaptation involves a sequence of developmental steps that parallel the phases of cognitive development (Nahl \& James, 1996; Nahl, 1998a). Affective information behaviors are reactions to motivational states and goal-directed thinking. These affective states and cognitive processes are both internally ordered by the social value (affective) and the structure (cognitive) of the information environment. Affective reactions are always bi-polar, either positive or negative. The influence of positive affect on cognitive processes has been shown to facilitate learming in many areas of human endeavor (Isen, et al. 1987; Bandura, 1997).

Nahl (1998b) shows that affective information behaviors are organized hierarchically by the cultural socialization experience that searchers bring to a search situation. Although both affective and cognitive behaviors are internal or private, their structure, content, and conditions of operation are culturally prescribed and internalized by normal individuals. Hence, people with different socialization backgrounds exhibit variant forms of cognitive and affective behaviors in particular situations.

Affective information behaviors include culturally structured motivational states such as the need to search and find information for personal motives. The acquisition of cognitive literacy depends on this prior cultural organization of affective goals and motives because cognitive skills cannot be acquired apart from the motivational state of the learner. Cognitive information becomes of relevance and interest only to the extent that it promotes the culturally organized affective goals of each searcher. Without this affective support, information does not acquire value to the individual. Nahl (1998b) has shown that searchers maintain "affective filters" that are set to keep out or ignore, anything that is felt to be not relevant to the searcher's definition of the search topic.

Four major dynamic concepts were established in a previous study of affective measures (Nahl, 2004). The first is self-efficacy (SE), defined as the motivation and skill to oppose self-criticism and self-doubt that are activated by uncertainty and temporary failure (Bandura, 1986; 1997; Compeau \& Higgins, 1995; 1999; Nahl 1996a). Compeau and Higgins (1995; 1999) empirically verified the relationship between computer self-efficacy and computer use. Staples, et al. (1998) found that those with high levels of self-efficacy in remote computing situations were more productive and satisfied, and better able to cope when working remotely. A second affective measure is optimism (Op), defined as the motivation to enlarge the range of cognitive activity in problem-solving, leading users to try different things when discouraged or facing an obstacle (Carver \& Scheier, 2001; Isen, et al., 1987). A third affective 
component is affective coping skills (ACS), previously termed "user coping skills" (UCS). ACS is defined as motivation and skill to counteract the negative feelings associated with "uncertainty" in the information environment: stress, pressure, irritation and frustration (Carver et al., 1996, 37-39). Task completion motivation (TCM) is defined as the degree of importance of the task added to how upset the person would be if the search task failed. TCM influences many aspects of search behavior relating to persistence and repeated postponement of quitting in the face of uncertainty.

According to affective load theory, successful information behavior depends on positive affective forces successfully counteracting the negative forces that constitute the affective load that are operating on the individual in information intensive environments. The negative forces are uncontrolled reactions to uncertainty, which almost always accompanies certain phases of information seeking. Uncertainty manifests itself in negative feelings - stress, pressure, irritation and frustration. The initiation of these negative feelings begins the sequence of quitting. To postpone quitting, the individual must act to neutralize the negative feelings with positive. In the present study, this counterbalancing skill is termed affective coping skills. Two components of this skill have been reliably isolated, namely, self-efficacy and optimism (see the literature review in Nahl, 2004).

The present study has two major purposes. One is to test the stability of the previous findings on affective load theory (Nahl, 2004). The sample in this study is comparable in population characteristics to the earlier sample. The rating scales have been somewhat edited to adapt to the new group and purpose. It is important to demonstrate that the earlier dynamics of affective load theory remain statistically demonstrable with a fresh sample under slightly different but comparable conditions. The second purpose of the study is to examine the prediction that affective load theory interacts dynamically with cognitive information behaviors.

\section{Design}

The 55 participants in this study were senior college students enrolled in an upper-division social sciences course in three subsections meeting at different times. The course required them to perform various information intensive tasks through the first half of the semester. Students were informed during the first week that they are expected to learn how to perform the following tasks:

1. Register online as a computer lab user by going to a designated URL. 
2. Email the instructor when the various tasks are completed.

3. Find a designated shopping item on the Web (bronze mailbox or metal cold drink bottle), copy the picture and item specifications, and paste them into their report.

4. Find a designated journal article in the university library's Web-based full text journal databases, copy and paste the abstract in their report, and some additional particulars.

5. Create a Home Page on a designated server with links to their reports.

6. Download free FIP software and use it to upload their work on the designated server.

7. Implement an effective Home Page information structure, linking to their various uploaded files (reports, outlines, Web research activities, book reviews).

8. Participate weekly in class forum discussions in a designated Web facility.

Over 80 percent of the students were somewhat familiar with all but projects 5, 6 and 7. Approximately 10 percent of students failed to complete the assigned tasks, either withdrawing or getting an $\mathrm{F}$. The rest completed all tasks within the deadlines given and received grades ranging from $A$ to $C$. In class discussions, students often voiced frustration and stress during the weeks of the projects. But at the end, they were near unanimous in reporting that they had gained significant new skills and were satisfied with their new Internet skills.

These details are mentioned to put in focus the context of the information intensive environment and the type of participants. This article presents the results for an affective and cognitive structured self-report questionnaire filled out in their second week, once they had an accurate idea of what was expected of them over the following weeks.

The design of this experiment involved setting up an information intensive environment in which participants are told in advance what information behaviors they will have to learn to perform within a few weeks. The experimental intervention includes the setting of significant motivation that is attendant to success or failure in performance. Students had to feel and know that their grade was at stake, and consequently their upcoming professional or graduate school career plans. Students also had to feel and know what details of their performance would be evaluated.

This experimental setting for information behavior invokes the natural affective dynamics investigated in this study (Bandura, 1997: 
113). If personal stakes are high and student involvement is strong, the setting is favorable for the occurrence of significantly intense affective reactions for the majority of students (Bandura, 197: 122). These affective information behaviors are set in motion when students fully comprehend what information skills they will need to learn and demonstrate to avoid the negative consequences of failure. The data explored in this study therefore relate to this anticipatory state of motivation and affectivity.

The affective self-report included 14 rating scales, see Table 1 . The rationale and operational definitions of the affective measures are given in an earlier study (Nahl, 2004). Tables 5 and 6 present samples of open-ended, cognitive responses to the affective scales.

During the second week, students were also given a cognitive performance task. An attempt was made to devise a task with face validity as a routine skill needed to succeed in the assigned information projects. The following written instructions were given:

This is a timed test. You have 10 minutes. You just finished typing a document and turned off the computer. Suddenly you remember you forgot to paginate the document. So you turn on the computer again. From memory, list the steps you have to go through to open your document again, paginate it, close the application, and then turn off the computer again. There are actually about 14 steps involving clicking or selecting from a menu or dialog box.

In the scoring procedure one point was given for every step that could be interpreted as accurate and belonged in the series of steps needed to perform the pagination task. The mean score was 9.47 correctly listed steps. The range was 2 to 14 , SD 3.32. These scores were used to create the cognitive high-low comparisons presented in the Results in Table 3.

Table 1. Definitions of Affective Measures and Group Means 


\begin{tabular}{|c|c|c|c|}
\hline $\begin{array}{l}\text { Affective } \\
\text { Measures }\end{array}$ & $\begin{array}{c}\text { Content } \\
\text { of Scales and Questions } \\
(1=\text { little; } 10=\text { much })\end{array}$ & $\begin{array}{l}\text { Current } \\
\text { Means } \\
\mathrm{N}=55\end{array}$ & $\begin{array}{c}\text { Nahl, } \\
2004 \\
\text { Means } \\
N=73\end{array}$ \\
\hline $\begin{array}{l}\text { Expected Effort } \\
\text { (Ex Eff) }\end{array}$ & $\begin{array}{l}\text { Expected effort (Q.9) and Expected } \\
\text { amount of work (Q.1) }\end{array}$ & $\begin{array}{c}8.48 \\
(8.71+8.24)\end{array}$ & 6 \\
\hline $\begin{array}{l}\text { Optimism } \\
\text { (Op) }\end{array}$ & Optimistic to do well (Q.8) & 7.93 & 8 \\
\hline Self-Efficacy (SE) & $\begin{array}{l}\text { Sure of success (Q.4) + Getting } \\
\text { good at }(Q .5)\end{array}$ & $\begin{array}{c}8.08 \\
(8.00+8.15)\end{array}$ & 8 \\
\hline $\begin{array}{l}\text { Task Completion } \\
\text { Motivation (TCM) }\end{array}$ & $\begin{array}{l}\text { Important to succeed }(Q .2)+\text { Upset } \\
\text { if unable to complete }(Q .3)+\text { How } \\
\text { motivated to complete }(Q .7)\end{array}$ & $\begin{array}{l}9.20 \\
(9.71+8.93 \\
+8.96)\end{array}$ & 7 \\
\hline Uncertainty $(U)$ & $\begin{array}{l}\text { Stress \& pressure }(Q .10)+ \\
\text { Frustration \& irritation }(Q .11)\end{array}$ & $\begin{array}{c}7.15 \\
(7.44+6.86)\end{array}$ & 3 \\
\hline $\begin{array}{l}\text { Affective Coping } \\
\text { Skills } \\
(A C S=S E+O p)\end{array}$ & $\begin{array}{l}\text { Self-efficacy }(Q .4+5)+\text { Optimism } \\
(Q .8)\end{array}$ & $\begin{array}{l}8.03 \\
(8.00+8.15 \\
+7.93)\end{array}$ & 8 \\
\hline Acceptance (Acc) & $\begin{array}{l}\text { Supportive of system (Q.12) + For } \\
\text { personal use }(Q .13)\end{array}$ & $\begin{array}{c}7.84 \\
(7.54+8.13)\end{array}$ & 6 \\
\hline $\begin{array}{l}\text { Affective Load } \\
(\mathrm{AL}=\mathrm{U} * \mathrm{Cl})\end{array}$ & $\begin{array}{l}\text { Stress \& Pressure }(Q .10)+ \\
\text { Frustration \& Irritation }(Q .11) * \\
\text { Computers are intimidating }(\mathrm{Cl}) \\
(\mathrm{Q} .14)\end{array}$ & $\begin{array}{l}60.06 \\
(7.44+6.86) \\
*(4.20)\end{array}$ & 123 \\
\hline Felt Locus of & Luck / Help from others / Own skills & & ----- \\
\hline
\end{tabular}




\begin{tabular}{|c|l|c|c|}
\hline $\begin{array}{c}\text { Affective Load } \\
(\mathrm{AL}=\mathrm{U} * \mathrm{Cl})\end{array}$ & $\begin{array}{l}\text { Frustration \& Irritation }(\mathrm{Q} .11) * \\
\text { Computers are intimidating }(\mathrm{Cl}) \\
(\mathrm{Q} .14)\end{array}$ & $\begin{array}{c}(7.44+6.86) \\
*(4.20)\end{array}$ & 123 \\
\hline $\begin{array}{c}\text { Felt Locus of } \\
\text { Control }\end{array}$ & $\begin{array}{l}\text { Luck / Help from others / Own skills } \\
(\mathrm{Q} .6)\end{array}$ & 7.76 & ----- \\
\hline
\end{tabular}

\section{Results}

Table 1 lists the affective measures used, definitions and the group mean for each scale, along with comparisons to results in a prior study using similar measures (Nahl, 2004). In the current design, there was an attempt to increase the difficulty of the information tasks that students were facing for the semester. This manipulation apparently succeeded as shown by higher Task Completion Motivation scores for the current experimental conditions ( 9 vs. 7 on the 10-point scale). This is also shown by the highly significant correlation between expected effort (Ex Eff) (Elzer et al., 2003) and Uncertainty ( $r=53$ ).

A dynamic relationship seems to exist between Expected Effort, Uncertainty, and Task Completion Motivation (TCM). When the information tasks appear more difficult, expected effort (Ex Eff) goes up (8. vs. 6), and so does Uncertainty (7 vs. 3). At the same time the motivation to complete the tasks (TCM) is strengthened (9 vs. 7).

The scores for optimism, self-efficacy, and affective coping skills (UCS) are nearly identical for the two samples. Acceptance of the system is higher than before ( 8 vs. 6 ), but since the scales have been changed, the difference is ambiguous. A slightly different measure was used for Affective Load so the values may not be comparable.

The inter-correlations between the affective measures were examined. A statistically significant relation exists between Self Efficacy (SE) and Acceptance (Acc) and support of the system ( $r=45)$. When people feel confident that they can be good at some information task (higher SE), they are more supportive of the computer system they have to use. There is a significant negative correlation between selfefficacy and uncertainty $(r=.43)$, so that those with higher self-efficacy experienced less stress and frustration. At the same time, self-efficacy is negatively correlated with affective load (AL) $(r=.33)$, so that feelings of self-confidence counteract and reduce affective load in an information task. 
Acceptance and support of the system (Acc) is significantly correlated with affective coping skills (ACS) ( $r=45$ ). In other words, those who are able to cope better experience less affective load (AL), and are consequently more accepting of and supportive of the system.

Table 2. Affective Measures for High and Low Affective Coping Skills

\begin{tabular}{|c|c|c|c|}
\hline Affective & $\begin{array}{c}\text { Group with } \\
\text { Higher } \\
\text { Affective } \\
\text { Coping } \\
\text { Skills } \\
\text { (N=37) }\end{array}$ & $\begin{array}{c}\text { Group with } \\
\text { Lower } \\
\text { Affective } \\
\text { Coping Skills } \\
\text { (N=18) }\end{array}$ & $\begin{array}{c}\text { ANOVA } \\
\text { Significance }\end{array}$ \\
\hline $\begin{array}{c}\text { Expected Effort } \\
\text { (Ex Eff) }\end{array}$ & 8.41 & 8.61 & $\begin{array}{c}\mathrm{F}=0.68 \\
\mathrm{p}(\mathrm{n} . \mathrm{s} .)\end{array}$ \\
\hline $\begin{array}{c}\text { Optimism } \\
\text { (Op) }\end{array}$ & 8.95 & 5.83 & $\begin{array}{c}\mathrm{F}=88.33 \\
\mathrm{p}<.0001^{\star \star}\end{array}$ \\
\hline Self-Efficacy (SE) & 8.80 & 6.59 & $\begin{array}{c}\mathrm{F}=70.92 \\
\mathrm{p}<.0001^{\star *}\end{array}$ \\
\hline $\begin{array}{c}\text { Task Completion } \\
\text { Motivation (TCM) }\end{array}$ & 9.33 & 8.93 & $\begin{array}{c}\mathrm{F}=2.78 \\
\mathrm{p}=.10^{*}\end{array}$ \\
\hline Uncertainty (U) & 6.88 & 7.70 & $\begin{array}{c}\mathrm{F}=3.93 \\
\mathrm{p}=.053^{* \star}\end{array}$ \\
\hline
\end{tabular}




\begin{tabular}{|c|c|c|c|}
\hline Motıvatıon (ICM) & & & $p=.10^{x}$ \\
\hline Uncertainty (U) & 6.88 & 7.70 & $\begin{array}{c}F=3.93 \\
p=.053^{\star \star}\end{array}$ \\
\hline Acceptance (Acc) & 8.16 & 7.12 & $\begin{array}{c}F=5.47 \\
p=.023^{\star \star}\end{array}$ \\
\hline $\begin{array}{l}\text { Affective Load } \\
\qquad(\mathrm{AL}=\mathrm{U} * \mathrm{Cl})\end{array}$ & 50.89 & 83.11 & $\begin{array}{l}F=5.85 \\
p=.019^{\star \star}\end{array}$ \\
\hline $\begin{array}{l}\text { Felt Locus of } \\
\text { Control }\end{array}$ & 7.89 & 7.50 & $\begin{array}{l}F=1.41 \\
p(. n . s)\end{array}$ \\
\hline
\end{tabular}

Table 2 shows the results of contrasting the affective measures for those with high vs. low affective coping skills. The scores for coping skills were split at the mean of the distribution. The ratio between the High-Low groups was two to one in favor of the High scores, i.e., a skewed distribution towards the upper end of the scale (mean=8). Significant differences were found for most of the measures, confirming and strengthening the earlier sample (Nahl, 2004).

High coping skills provide a significant affective advantage as indicated by higher optimism, stronger selfeefficacy, lower uncertainty, higher support and acceptance of the system and less affective load. Task completion motivation was also higher, but in this case both groups approach the high end of the scale so that there is less room for differentiation. An interesting detail is that the standard error for the high coping group is consistently half of the low coping group for every measure (.2 of the rating scale unit vs. .4 or higher). This indicates less affective variability or greater affective stability, and is part of the dynamic properties of affective coping. Those who have less coping skills experience less affective stability, that is, less control over their feelings and emotions when faced with information tasks. This possibility needs to be further investigated, and especially, whether affective coping skills can be increased by design features in the information environment.

Table 3 presents new findings that were not investigated previously. This sample was given a cognitive pre-task to perform that measures the ability to reconstruct from memory the keyboard steps required for opening a document in a word processor, 
Table 3. Relation Between Affective and Cognitive Measures

\begin{tabular}{|c|c|c|c|}
\hline Affective & $\begin{array}{c}\text { Group with } \\
\text { Higher } \\
\text { Cognitive } \\
\text { Skills } \\
\text { (N=32) }\end{array}$ & $\begin{array}{c}\text { Group with } \\
\text { Lower } \\
\text { Cognitive } \\
\text { Skills } \\
\text { (N=21) }\end{array}$ & $\begin{array}{c}\text { ANOVA } \\
\text { Significance }\end{array}$ \\
\hline $\begin{array}{c}\text { Expected Effort } \\
\text { (Ex Eff) }\end{array}$ & 8.38 & 8.53 & $\begin{array}{c}\mathrm{F}=0.38 \\
\mathrm{p}(\mathrm{n} . \mathrm{s} .)\end{array}$ \\
\hline $\begin{array}{c}\text { Optimism } \\
\text { (Op) }\end{array}$ & 8.47 & 7.33 & $\begin{array}{c}\mathrm{F}=5.69 \\
\mathrm{p}=.021^{\text {** }}\end{array}$ \\
\hline Self-Efficacy (SE) & 8.35 & 7.69 & $\begin{array}{c}\mathrm{F}=2.91 \\
\mathrm{p}=.094^{*}\end{array}$ \\
\hline $\begin{array}{c}\text { Task Completion } \\
\text { Motivation (TCM) }\end{array}$ & 9.30 & 8.97 & $\begin{array}{c}\mathrm{F}=1.92 \\
\mathrm{p}(\mathrm{n} . \mathrm{s} .)\end{array}$ \\
\hline Uncertainty (U) & 7.13 & 7.35 & $\begin{array}{c}\mathrm{F}=0.26 \\
\mathrm{p}(\mathrm{n} . \mathrm{s} .)\end{array}$ \\
\hline Affective coping & & & $\mathrm{r}-1.20$ \\
\hline
\end{tabular}




\begin{tabular}{|c|c|c|c|}
\hline Uncertainty (U) & 7.13 & 7.35 & $\begin{array}{c}F=0.26 \\
p(n . S .)\end{array}$ \\
\hline $\begin{array}{c}\text { Affective coping } \\
\text { Skills } \\
\text { (UCS=SE+Op) }\end{array}$ & 8.39 & 7.57 & $\begin{array}{c}F=4.23 \\
p=.045^{\star \star}\end{array}$ \\
\hline Acceptance (Acc) & 7.58 & 8.12 & $\begin{array}{c}F=1.51 \\
p(n . s .)\end{array}$ \\
\hline $\begin{array}{c}\text { Affective Load } \\
\text { (AL=U * Cl) }\end{array}$ & 60.63 & 63.76 & $\begin{array}{c}F=0.05 \\
p(n . s .)\end{array}$ \\
\hline $\begin{array}{c}\text { Felt Locus of } \\
\text { Control (luck, } \\
\text { others, self) }\end{array}$ & 8.07 & 7.24 & $\begin{array}{c}F=7.46 \\
p=.009^{\star *}\end{array}$ \\
\hline
\end{tabular}

The group was divided at the mean of the distribution of the cognitive task scores. The distribution was slightly skewed with a few more in the high group. Three of the measures obtained clear significant differences. The high cognitive skills group reported significantly higher optimism, higher affective coping skills and higher felt exercise of control. They also reported higher self-efficacy, as predicted, but with near significance levels (one way test). A larger sample will be used in a replication experiment. The other measures were clearly not significant.

The pattern of significances gives indications of the dynamic interaction between affective and cognitive behavior in information contexts. It is clear from these results that cognitive and affective skills enhance each other (Isen, 1987). Future research will have to develop an appropriate design to investigate how this important interaction actually takes place and whether it represents a causeeffect or correlational relationship. 
Table 4 provides some information as to the possible nature of the affective-cognitive interaction effect. The sample was divided into four sub-groups on the basis of their joint affective and cognitive scores. Affective load and Acceptance were then calculated for each sub-group. The means in Table 4 indicate a distinct disadvantage for those who had both low affective coping skills and low cognitive skills (Lo, Lo). They experienced relatively high affective load (89) with low acceptance of the system (14). On the other hand, high coping skills can make up for low cognitive skills (Hi, Lo), experiencing less affective load (41) and relatively greater acceptance and support of the system (18).

The effect of high affective coping skills is seen even more clearly in contrasting the two $\mathrm{Hi}, \mathrm{Hi}$ and $\mathrm{Hi}$, Lo sub-groups with the $\mathrm{Lo}, \mathrm{Hi}$ and Lo, Lo sub-groups. (top two rows vs. bottom two rows). Average affective load for two Hi affective coping sub-groups is 51 , while it is 83 for the two Lo affective coping skills groups. This difference is highly significant $(F=5.85, p=019 * *)$. The same finding holds for acceptance and support for the system. The difference between the top two and bottom two rows is significant (16 vs. 14, $F=5.47$, $\left.\mathrm{p}=023^{* *}\right)$. To some extent, higher affective skills compensate for lower cognitive skills. This likely occurs because positive affect permits consideration of more alternative paths (Isen, 1987; Norman, 2004: 19), thus increasing the likelihood of finding a productive path.

Table 4. Interaction Effects Between Affective and Cognitive Information Behavior 


\begin{tabular}{|l|c|c|c|}
\hline \multicolumn{1}{|c|}{$\begin{array}{c}\text { Combination of } \\
\text { Affective and Cognitive } \\
\text { Skills }\end{array}$} & Contrast & $\begin{array}{c}\text { Affective } \\
\text { Load (AL) } \\
(\mathbf{p = n . s . )}\end{array}$ & $\begin{array}{c}\text { Acceptance } \\
\text { of the System } \\
\text { (Acc) } \\
(\mathbf{p = n . s . )}\end{array}$ \\
\hline $\begin{array}{l}\text { High Affective Coping Skills } \\
\text { with High Cognitive Skills }\end{array}$ & $\mathrm{Hi}, \mathrm{Hi}$ & 57 & 15 \\
\hline $\begin{array}{l}\text { High Affective Coping Skills } \\
\text { with Low Cognitive Skills }\end{array}$ & $\mathrm{Hi}, \mathrm{Lo}$ & 41 & 18 \\
\hline $\begin{array}{l}\text { Low Affective Coping Skills } \\
\text { with High Cognitive Skills }\end{array}$ & Lo, Hi & 73 & 14 \\
\hline $\begin{array}{l}\text { Low Affective Coping Skills } \\
\text { with Low Cognitive Skills }\end{array}$ & Lo, Lo & 89 & 14 \\
\hline
\end{tabular}

Another way of looking at the affective-cognitive interaction effect in information behavior is to examine representative explanations students offer for their affective ratings of the information tasks they have been assigned. Table 5 illustrates a sample and range of responses. The sentence "Please add an explanation for your rating" appeared after each scale in order to connect the affective rating with the cognitive explanation or justification for it. Those with a relatively lower self-efficacy orientation, who give an affective rating of 5 , engage in cognitive operations that focus on their limitations in ability, experience or understanding.

In contrast, those who give a higher affective rating of self-confidence (7) seem to balance their feeling of limitation in this situation with their past successes. Those who rate themselves as highly self-confident (10), focus on their capacity for mastery. Future research can determine whether a cognitive focus on prior success and mastery can be encouraged or prompted in information settings as a design feature. Enactive mastery, gained by reflecting upon one's own successful past performances, is a powerful 
source of self-efficacy. Enactive mastery of complex behaviors such as Internet use can be bolstered by steadily building upon the successful attainment of sub-skills that are relatively easy to master (Eastin \& LaRose, (2000). If more skillful cognitive justifications can be prompted, they might facilitate a more positive affective orientation to the tasks and the system and thereby improve success, efficiency and satisfaction.

Table 5. Sample of Cognitive Explanations for Affective Ratings (Self Efficacy SE)

\begin{tabular}{|c|l|}
\hline Rating given for Q.5 & $\begin{array}{l}\text { 5) How likely is it that you will become good at the types of tasks } \\
\text { that are required in this course? 1=pretty doubtful; 10=almost } \\
\text { certain }\end{array}$ \\
\hline 5 & $\begin{array}{l}\text { Sample Explanations Given } \\
\text { I I haven't understood class tasks well } \\
\text { I am worried about my language ability a lot. } \\
\text { - I would like to learn more about how to use computers because my } \\
\text { skills are limited, but I find that I don't really like doing things on the } \\
\text { computer-other than email, papers \& pictures. }\end{array}$ \\
\hline 8 & - I am a fast, strong learner. \\
- Cause I know what to expect \& do. \\
- It depends if I can understand things or not. Some things I can get \\
easily while other things are harder for me to get. \\
- I'm sure I'll pick it up quick. \\
- I enjoy mastering new things. I love taking apart concepts \& putting \\
them back together again. \\
- I feel that I'm a quick learner as far as computers go.
\end{tabular}


A similar examination is given for the optimism rating scale in Table 6 . Those who rate themselves as relatively less optimistic (5) give cognitive justifications focusing on the unfamiliarity of the information environment. Their cognitive philosophy is to wait and see before committing to optimistic expectations. Those with higher optimism feelings ( 8 and 10 ) focus cognitively on making the necessary effort and their preparation for it.

Table 6. Sample of Cognitive Explanations for Affective Ratings (Optimism Op)

\begin{tabular}{|c|c|}
\hline Rating given for Q.8 & $\begin{array}{c}\text { 8) How optimistic are you that you will do well in this course? } \\
\text { 1=not optimistic; } \begin{array}{c}\text { 10-very optimistic } \\
\text { Sample Explanations Given }\end{array}\end{array}$ \\
\hline 5 & $\begin{array}{c}\text { I need to see the syllabus and how the first week goes in order to see } \\
\text { my success in this course. }\end{array}$ \\
& $\begin{array}{c}\text { I am not sure yet about this course because I have not read the } \\
\text { lecture notes and textbook. } \\
\text { So far, I haven't experienced this type of class, so I feel nervous } \\
\text { about it. }\end{array}$ \\
\hline 8 & $\begin{array}{l}\text { I will try my best and not fail at being an excellent student. } \\
\text { I am worried of my ability, but the same time, I will make a lot of effort. } \\
\text { Therefore, I am pretty much optimistic about my effort. } \\
\text { I know it is hard work but I am prepared. } \\
\text { Seems like this course is very structured. If I can stay on schedule I } \\
\text { should be ok. } \\
\text { Seems like a fun course. With hard work and motivation, I feel that I } \\
\text { will succeed. }\end{array}$ \\
\hline 10
\end{tabular}




\section{Discussion and Conclusion}

This study had two purposes. The first was to test the stability of prior findings from an affective load theory study (Nahl, 2004). It is clear from these findings that the affective dynamics encountered in information intensive environments are measurable, stable and significant. In the prior study people faced a specific search task during a limited search session, while in this study students were facing several weeks of information projects for which they felt only partially prepared, yet were responsible for completion within deadlines. Despite the great difference in information locality or psychological condition, the affective dynamics were found to be very similar in both information situations. Self-efficacy and optimism continue to afford significant coping advantages in the face of the negative effects of uncertainty in goal-completion.

The second purpose of this study was to attempt to demonstrate a key element of affective load theory, namely, that it interacts dynamically with cognitive information behaviors. The results show that higher affective coping skills such as self-efficacy and optimism, afford an advantage in information situations for people with lower cognitive skills. Higher affective coping skills benefit those with low or high cognitive skills. However, those with higher cognitive skills and low affective coping skills may experience less success and more stress.

These findings strengthen the claims of information behavior researchers who call for greater attention to the user's affective information world, both in terms of emotional design of systems (Norman, 1990; 2004; Green et al., 2002) and psychological climate of the information setting (Nahl, 1992). Future research is needed to test the extensiveness of the affective-cognitive interaction demonstrated in this study. It is especially important to investigate the methods by which the affective information environment of users can be assisted and managed.

\section{References}

Bandura, A. (1986). Social foundations of thought and action: A social cognitive theory. Englewood Cliffs, NJ: Prentice-Hall.

Bandura, A. (Ed.). (1997). Self-efficacy: The exercise of control. New York: W.H. Freeman. 
Carver, C. S., Lawrence, J. W. \& Scheier, M. F. (1996). A control-process perspective on the origins of affect. In L. L. Martin \& A. Tesser. (Eds.), Striving and feeling: Interactions among goals, affect and self-regulation (pp. 11-52). Mahwah, N.J.: Lawrence Earlbaum Associates.

Carver, C. S., \& Scheier, M. F. (2001). Optimism, pessimism, and self-regulation. In E. C. Chang (Ed.), Optimism and pessimism: Implications for theory, research, and practice (pp. 31-51). Washington, DC: American Psychological Association.

Compeau, D., \& Higgins, C. (1995). Computer self-efficacy: Development of a measure and initial test. MIS Quarterly, 19, 189211.

Compeau, D., \& Higgins, C. (1999). Social Cognitive Theory and individual reactions to computing technology: A longitudinal study. MIS Quarterly, 23, 145-158.

Eastin, M. S. \& LaRose, R. (2000). Internet self-efficacy and the psychology of the digital divide. JCMC 6(1) September. Retrieved June 22, 2005 from http://www.ascusc.org/jcmc/vol6/issue1/eastin.html

Elzer, S., Green, N. \& Carberry, S. (2003). Exploiting cognitive psychology research for recognizing intention in information graphics. In Proceedings of the 25th Annual Meeting of the Cognitive Science Society, Boston, August. Retrieved June 22, 2005 from http://www.cis.udel.edu/ carberry/Papers/CogSci-03.pdf

Green, W. S. and Jordan, P. W. (Eds.). (2002). Pleasure with products: Beyond usability. Boca Raton, FL: CRC Press.

Isen, A. M., Daubman, K. A. \& Gorgoglione, J. M. (1987). The influence of positive affect on cognitive organization: Implications for education. In R. E. Snow \& M. J. Farr (Eds.), Aptitude, Learning, and Instruction. Volume 3: Cognitive and Affective Process Analyses (pp. 143-164). Hillsdale, NJ: Lawrence Erlbaum Associates.

Nahl, D. \& James, L. (1996). Achieving focus, engagement, and acceptance: Three phases of adapting to Internet use.

Electronic Journal of Virtual Culture (February) 4 (1). Retrieved June 22, 2005 from

http://www.soc.hawaii.edu/leonj/leonj/leonpsy/instructor/compedutext.html 
Nahl, D. (2005 in press). Affective load theory (ALT). In K E. Fisher, S. Erdelez, \& E. F. McKechnie (Eds.), Theories of information behavior: $A$ researcher's guide. Medford, NJ: Information Today.

Nahl, D. (1996a). Affective monitoring of Internet learners: Perceived self-efficacy and success. In Proceedings of the 59th ASIS Annual Meeting, 33 (pp. 100-109), Medford, NJ: Information Today.

Nahl, D. (1998b). Ethnography of novices' first use of web search engines: Affective control in cognitive processing. Internet Reference Services Quarterly, 3(2): 51-72.

Nahl, D. (1998a). Learning the Internet and the Structure of Information Behavior. Journal of the American Society for Information Science, 49(11), 1017-1023.

Nahl, D. (2004). Measuring the Affective Information Environment of Web Searchers. In Proceedings of the 67th ASIST Annual Meeting, 41 (pp. 191-197), Medford, NJ: Information Today.

Norman, D. A. (2004). Emotional design: Why we love or hate everyday things. New York: Basic Books.

Norman, D. A. (1990). The design of everyday things. New York: Basic Books.

Staples, D. S., Hulland, J. S., \& Higgins, C. A. (1998). A self-efficacy theory explanation for the management of remote workers in virtual organizations. Journal of Computer-Mediated Communication [On-line], 3(4). Retrieved June 22, 2005 from: http://www.ascusc.org/jcmc/vol3/issue4/staples.html 